\title{
Employee participation and representation in Central and Eastern Europe
}

\begin{abstract}
Using data from the 2013 European Company Survey we study employee involvement and participation (EIP) in decision-making in twelve Central and Eastern European (CEE) countries, a context that is rather less studied but interesting because of its political past and its current emerging economic status. We explore how these countries can be clustered according to positive employee attitude towards employee representation and EIP in decision-making. We examine the association between these two components and the effectiveness of the employee representation (ER) body, as well as whether there are differences between country clusters. Finally, we examine how the degree of EIP in decisionmaking is related to ER body effectiveness. Our study contributes to prior work by seeking to understand EIP in decision-making in an understudied sample of CEE countries and provides an insightful classification.
\end{abstract}

Keywords Employee involvement and participation, Decision-making, Employee representation, Post-communist countries, Central and Eastern Europe, Clusters 


\section{Introduction}

Employee involvement and participation (EIP) in decision-making encompasses a variety of different approaches including representative formal systems, direct formal meetings and informal interactions (Marchington, 2015). We define EIP in decision-making as any workplace process that "allows employees to exert some influence over their work and the conditions under which they work" (Strauss, 1998: 15). Until the 1980s, it was seen as being very much about representative bodies such as Joint Consultative Committees (JCCs), which provided opportunities for employee representatives to meet with managers to discuss workplace issues. In the 1990s there was more interest shown in direct formal EIP in decision-making where managers interact directly with their staff rather than via employee representatives. Team briefings and problem-solving schemes, such as quality circles, were examples of this and these mechanisms, although designed primarily to help managers with business improvements, also often provided opportunities for workers to raise issues and concerns. Informal EIP in decision-making refers to more ad hoc interactions between managers and their staff (Marchington, 2015). In this paper we focus on the more embedded forms of EIP in decision-making, namely indirect forms where workers are represented by one of their co-workers or trade union officials on a formal committee (Marchington and Kynighou, 2012).

EIP in decision-making is seen as a crucial element in creating a positive employee relations climate, achieving successful organisational change, as well as driving financial performance, reducing turnover rate and improving workforce morale (Riordan et al., 2005). Indirect EIP in decision-making can have varying outcomes with representatives' power varying from having a vote on the boards of directors to a more advisory voice on a workers' council (Cotton et al., 1988). It is particularly intriguing to investigate indirect forms of EIP in decision-making given the decline of collective representational forms in the Anglo- 
American world (Freeman et al., 2007) and across the developed economies of Western Europe (Kessler et al., 2004). The recent financial crisis has intensified the deterioration of collective bargaining in the context of significant labour market change. (Johnstone et al., 2019) Some suggest that indirect EIP in decision-making is less effective than it was, with employers reducing consultation with their staff within the climate of the crisis (Marchington and Kynighou, 2012).

Much more is known about the trend of weakening collective representational forms and how this affects the effectiveness of EIP in decision-making in Western European contexts than in the emerging economies of post-communist Central and Eastern Europe (CEE) (Psychogios et al., 2016). A major reason for this has been the lack of suitable quantitative data, which has stalled research on this topic. Another reason is that small and medium enterprises (SMEs) and informal economic activity prevail in these economies (Williams, 2015), thus limiting the opportunities for studying indirect forms of EIP in decision-making.

What we know is that formal institutional industrial relations (IR) in CEE were at best only partially established after the collapse of the Soviet regime (Hyman, 2018). According to Soulsby et al. (2017), the collapse of communist governments left a vacuum of regulatory frameworks, which was filled by institutional transfer from international sources, such as the IMF, the World Bank and the European Bank for Reconstruction and Development. This entailed a "shock therapy" (McCann and Schwartz, 2006) for many countries due to the immediate introduction of free market conditions and the dismantling of communist structures. The result was a rise in unemployment, a decline in living standards, intensification of work and chronic job insecurity (Korkut et al., 2016). This situation has been exacerbated by the global financial crisis, although the CEE countries have been less 
affected than other Western economies because they have not yet fully integrated into financialised global capitalism (Hyman, 2018).

IR in the CEE region have experienced a decline in trade union membership, declining coverage by collective agreements and low influence on public policy (Ivlevs and Veliziotis, 2016). Much of this decline has been attributed to the transition of the region to democracy and the consequent accession to the EU of most of the CEE countries in recent years. This period resulted in a change from a system of compulsory union membership to a system of voluntary membership and to the rise of the non-unionised private sector (Ivlevs and Veliziotis, 2016). These large structural economic changes and the widespread perception of unions as the "remnants of the old system" (Avdagic, 2005: 27) caused the decline in trade union density across post-communist countries. This perception was further fuelled by the way each country handled the transition in terms of internal political dynamics and decisions at union leadership level, often resulting from incentives offered by the transition governments (Lee and Trappmann, 2014). Research in some countries of the CEE region has so far found cross-country and sectoral variations in trade union approaches (see for example Mrozowicki, 2014, for an analysis of industrial relations and trade unions in Poland, Slovenia, Estonia and Romania). Formal mechanisms of representation in the region were weak and even when there were structures these were somewhat illusory because of the limited power and legitimacy of organised labour together with a lack of capacity of national institutions to emulate Western European practices (Varga 2013).

In this respect, a focus on the effectiveness of indirect forms of EIP in decisionmaking in the CEE context is timely. Despite the plethora of literature on EIP in decisionmaking in the Anglo-American world and across Europe (Freeman et al., 2007; Kessler et al., 2004; Wilkinson et al., 2010) we need to understand EIP in decision-making in relation to the organisational and social contexts in which they occur. We argue that this is case of CEE 
economies where the development of EIP systems has, reflecting economic development, been uneven, haltering and rendered volatile in the wake of the global financial crisis (Soulsby et al., 2017). This study, therefore, foregrounds the countries of Bulgaria, Croatia, Czech Republic, Estonia, FYROM, Hungary, Latvia, Lithuania, Poland, Romania, Slovakia and Slovenia. The historical context for the analysis is the weak EIP representational forms and the negative perceptions of their effectiveness (Avdagic, 2005).

The notion that Europe can be divided into clusters is common, although clusters that have been presented so far do vary depending on the topic of discussion (Brewster, 2004). Most of the studies in management literature attempting to categorise countries based on various employment aspects are conducted in western contexts (Cooke et al., 2011) which, among other attributes, tend to have strong and established institutional bases. Yet, the literature on employment relations in CEE countries is more fragmented and partial (Larsen and Navrbjerg, 2013), because of the changing political and economic context (Psychogios et al., 2018). CEE countries are characterised by highly diverse institutional histories (Ivlevs and Veliziotis, 2017; Soulsby, 2017) and transition paths to democracy (Hardy, 2014). There is a lack of theoretical country 'clusters' on EIP in decision-making in this region. 'Clustering' has the potential to help us understand the key similarities/differences between groups, or clusters, of these CEE countries regarding EIP in decision-making. In this respect, this paper aims to explore three research questions: 1) How are CEE countries clustered according to employee attitude towards ER and EIP in decision-making? 2) How does employee attitude towards ER and EIP in decision-making relate to ER body effectiveness in the CEE context and are there any differences between country clusters? 3) How does the degree (low, medium, high) of EIP in decision-making relate to ER body effectiveness?

Results showed that, at the county-level of analysis, there are mainly two clusters of countries, while at the individual level of analysis there is evidence of an association between 
positive employee attitudes towards ER and ER body effectiveness and more solid evidence on the relationship between EIP in decision-making and ER body effectiveness. The next two sections provide the theoretical and contextual background of this study.

\section{Employee attitude towards employee representation, EIP in decision-making and relation to ER body effectiveness}

How an ER body can be perceived to be 'effective' by its members is related to managerial and employee attitudes towards representation and the interaction of these two parties (Franca and Pahor, 2014; Van den Berg et al., 2018). In this study, we focus on the 'employee' part of the employment relationship. Employees and their representatives need to value the process and outcomes of representation since their attitude influences the outcome of such practices and can enhance their voice within organisations (Dundon, et al., 2004). From an employee perspective, a positive attitude to representation would be to perceive the ER body as a necessary mechanism for successful negotiations with the employer (Bengtsson and Berglund, 2010), to value the outcome of employee representation (Buttigieg et al., 2014) and to express an interest in the outcomes of consultations and negotiations (Cotton et al., 1988). Individual employee motives for supporting an ER body could be ideological (a commitment to supporting the principle underlying the body or instrumental (support is seen as the best means to reach one's own goals) (Allvin and Sverke, 2000; Furåker and Berglund, 2003). Factors affecting employee attitude towards employee representation include union membership and socio-demographics (age, gender, education, occupation and political beliefs), institutional and organisational structure factors (Debono, 2017). For example, research has found that union members feel more positive about their union's effectiveness in dealing with working conditions and job security issues (Givan and Hipp, 2012) most likely because they would have already benefited from their union either through individual 
assistance or through collective bargaining (Debono, 2017). Similarly, in institutional environments supportive of unions, employees exhibit more positive attitudes towards their unions and their effectiveness (Turner and D’Art, 2012).

Apart from positive attitudes towards the ER body, what also matters in order for the ER body to be effective, is the actual participation of employees in decision-making. The evidence suggests that EIP in decision-making can benefit both employees and organisations (Strauss 2006). Studies of voice indicate that having the opportunity for "voice" has "valueexpressive" worth even if this is not linked to any influence over the decisions made (Tyler, 1987). There is also evidence suggesting that the degree of involvement matters. The "depth" of EIP in decision-making relates to the extent to which employees have a say about organisational decisions. A greater depth is seen where employees can influence those decisions that are normally reserved for management. The other end of the continuum may be a shallow depth, evident when employees are simply informed of the decisions management have made (Wilkinson et al., 2013). Many EIP schemes have been criticised for not meeting the standards of full participation (Pateman, 1970) although they can offer opportunities to influence workplace practices and change (Cox et al., 2006). Prior work has shown that a negative perception of the degree of EIP in decision-making by employees may lead to a negative organisational climate (Shadur et al., 1999). There is also evidence suggesting that when organisations insist on maintaining a low degree of involvement from their employees, improvement programmes have limited impact (Shapiro, 2000). Similar evidence has been found in south-eastern European countries (Psychogios, 2010).

Nevertheless, the arguments in favour of EIP in decision-making has been mainly formulated in western contexts, although "the function of the different participatory programmes, and the attitudes of the employees involved in these programmes, cannot be understood in isolation of an awareness and knowledge of the organisational context and the 
labour market traditions and culture where they take place" (Jeppesen et al., 2011: 70). There is still little research that has been undertaken on emerging European economies including CEE countries (Cooke et al., 2011; Psychogios et al., 2010). In other words, we know little about employee relations in general and EIP in decision-making in particular in postcommunist national contexts and this provides a good setting for our research to make a contribution to help understand the process of transition and emergence of these systems in these countries.

\section{Employee involvement and participation in decision-making in the Central and Eastern}

\section{European post-communist context}

Post-communist CEE countries are characterized by diverse institutional histories (Soulsby, 2017), including changes in political economy and social institutions (Ivlevs and Veliziotis, 2017), making their transition to democracy uneven and fragmented (Hardy, 2014). It is because of this variation that the established typologies within the comparative capitalism literature, which are largely static, fail to capture the developments in this region, which underwent a transformation from central planning to market economies.

None of the established clusters in the extant literature look at EIP in decision-making on which is the focus of this study and in general the CEE region has not been widely studied when creating such clusters. Bohle and Greskovits (2007) do present a CEE clustering, but their work is more focussed on economic issues and employment relations in general and EIP in particular are not well covered. Their work presents three variants of transnational capitalism emerging in CEE: a neoliberal type in the Baltic states (Estonia, Latvia, Lithuania), an embedded neoliberal type in the Visegrád states (Czech Republic, Hungary, Poland, Slovak Republic), and a neocorporatist type in Slovenia. Their research presents these typologies based on economic analyses of marketisation, industrial transformation, 
social inclusion and macroeconomic stability. Hence, as noted above their analysis is not specific to employment relations issues. Their clustering is also limited to a selected number of CEE countries. Nevertheless, this work provides insight on the different capitalist political economies that emerged from the transformation in the CEE region and demonstrates the diversity of these economies due to historical institutional legacies and perceptions over the reforms implemented. Our study focuses on the wider set of CEE counties and aims to understand how these countries can be categorised and explained according to employee attitude towards ER and EIP in decision-making. In turn, the clustering can provide a strong basis of a comparative perspective within this region, but also across different regions of other emerging economies in Asia and Africa, as well as across regions of more developed economies. Leszczynski (2015) argues that, although CEE countries share a post-communist heritage, they have developed diverse forms of capitalism attributed to three main factors. First, the former communist nations had developed a variety of communism between 1945 and 1989, despite having some commonalities between them in terms of their systemic political and economic features imposed by the Soviet Union. Second, the communist system legacy that shaped initial conditions for the transition of these economies also varied within countries. Third, transformation strategies also depicted variation. The existing political, economic and institutional conditions affected the speed at which reforms took place ("shock therapy" versus "gradualist approach"). Therefore, one can expect that ER and EIP practices in the CEE context will also demonstrate diversity, although some countries may be more similar than others in the way their IR systems have been transformed during the transition to democracy and the accession to the EU that followed.

Earlier work by Pollert (1999) in Poland, Hungary, Slovakia and the Czech Republic found that unions in this region have made substantial progress in establishing the institutional frameworks of labour representation. However, a common trend of trade union 
marginalisation in terms of diminished roles and influence as a consequence of economic deregulation and privatisation was observed (Pollert, 2000). Vliengenthart (2007) asserts that organised labour was a major loser in the restructuring of post-communist economies. Caught between former neo-corporatist structures and the competing dynamics of deregulation, formal and indirect EIP in decision-making is increasingly under pressure. Several commentators have observed declines in union density and influence in Estonia, Latvia, Lithuania (Sippola, 2009), Hungary (Richbell et al., 2010) and Croatia (Svetlik et al., 2010), variations in the ER system used (Meardi et al., 2009) (see Table 1). This is, in part, due to the changing political context, but also to the growth in non-unionised firms and sectors. The growing mass of unorganised workers is a major feature of the emerging CEE economies (Pollert, 2000). Political reform and economic recession combine to put greater emphasis on smaller and family-owned firms. Even where there are formalised ER systems and regulation, it is characteristic of the CEE context to be grappling with evasion of regulations (Psychogios et al., 2014).

In addition, there is evidence on the variation in the levels of board-level representation in private companies (ETUI, 2018), which can help us contextualise the "culture" of EIP practices in organisations in this region (see Table 1) primarily affected by the institutional/legal context. Looking at this data, the CEE region under study depicts a mix of countries ranging from those with no legislation facilitating representation at board level (Bulgaria, Latvia, Poland, FYROM, Estonia, Lithuania) and those countries who do facilitate ER at board level albeit with specific conditions (Croatia, Slovenia, Czech Republic, Hungary, Slovakia, Romania).

[Insert Table 1 about here]

On the face of it these trends suggest a pessimistic outlook for EIP in decision-making with few mechanisms for employee interests to be advanced. It is, therefore, appropriate to 
examine the effectiveness of indirect forms of EIP in decision-making in this context. However, multi-country comparative research on EIP in decision-making and employee attitude towards ER in this context is scarce. There has been one study across 12 European countries which was published by the IDE International Research Group (1981) almost four decades ago, which surveyed samples of employees on their perception of worker and management influence. More recent comparative studies on employee perceptions of voice and representation have been conducted (e.g. Bryson and Freeman, 2013; Edwards and Edwards, 2015), but these are relatively small-scale studies and do not focus on the CEE region. The first official quantitative study shedding light on EIP in decision-making in the European region is the European Company Survey (2013), which we are using in this paper.

We, therefore, are unable to use recent prior research to hypothesise how perceived employee attitude to ER and perceived EIP in decision-making might be associated with perceived ER body effectiveness in the CEE context. However, we know that institutions can shape employee expectations about the nature of EIP in decision-making, affecting employee perceptions of how satisfied they are with these processes (Edwards and Edwards, 2015; Kessler et al., 2004). Thus, we expect to see some variation in perceived employee attitude towards ER and perceived EIP in decision-making within the CEE context, given the diversity in their political, social and economic development.

\section{Research methodology}

Data and sample

To examine the main research questions of this study, we use data from the $3^{\text {rd }}$ wave of the European Company Survey (ECS) conducted by the European Foundation for the Improvement of Living and Working Conditions in 2013 (Kankaraš and Van Houten, 2015). The survey provides information from management representatives in over 24,000 
establishments with 10 employees or more and employee representatives in 6,800 of these establishments. Employee representation types in these institutions include trade union representation, shop stewards, works councils, joint platforms, and other non-union employee representation. The survey covers the EU28, the Former Yugoslav Republic of Macedonia (FYROM), Iceland, Montenegro, and Turkey. The analysis is based solely on the employee representatives' survey, which includes workplace practices, for example, in terms of the extent of employee representation, employee involvement in decision-making, functioning of employee representation, and work climate. All information describes employees' perceptions. The analysis is also restricted to 12 countries in Central and Eastern Europe, i.e. Bulgaria, Czech Republic, Estonia, Croatia, Latvia, Lithuania, Hungary, Poland, Romania, Slovenia, Slovakia, and FYROM. These restrictions and the differences in response rates across questions provided a total number of 2,195 observations.

\section{Variables}

The ECS 2013 contains questions that capture different facets of employee representation related to employee attitude towards ER, EIP in decision-making, and ER body effectiveness. Specifically, the survey has information about the influence of employee representation on management decisions, which is captured with a single-item question that asks employee representatives "thinking about the decision in the areas of organisation of work processes, recruitment and dismissals, occupational health and safety, training and career development, and working time arrangements in this establishment, would you say the ER-body had no influence, some influence or a strong influence on the management decision?". The variable is defined as perceived ER body effectiveness and is measured on a three-point scale, ranging from $0=$ no influence, $1=$ some influence, to $2=$ strong influence. 
Furthermore, the survey includes two questions about employee attitude towards ER that ask employee representatives to indicate the extent to which: a) employees value the work of the employee representation defined as value of ER and b) employees rarely express interest in the outcome of consultations or negotiations defined as interest in ER. The latter question is reverse coded to convey positive rather than negative employee attitude towards employee representation. The survey also includes a set of questions, which capture EIP in decision-making. One question asks the extent to which management makes sincere efforts to involve the employee representation in the solving of joint problems (problem solving). Another question asks "thinking about the decisions about the organisation of work processes, recruitment and dismissals, occupational health and safety, training and career development, and working time arrangements in this establishment, do you agree or disagree with the following statements?: the involvement of the ER body in the discussion on this issue reflects common practice in this establishment" (ER body as a common practice). Finally, the survey includes a question that asks respondents "thinking more generally about the involvement of employees in decision-making in this establishment, do you agree or disagree with the following statements: the ER-body should be involved more in decisionmaking in this establishment" (ER body involvement). The latter question is reversely coded, and all questions are measured on a four-point scale, ranging from $0=$ strongly disagree to 3 $=$ strongly agree.

The conceptual overlap between questions lead us to uncover a potential underlying factor structure associated with them and bring correlated variables together under more general variables. We performed principal component analysis ${ }^{1}$ in order to identify patterns of association across variables and express multivariate data with fewer factors or

\footnotetext{
${ }^{1}$ The difference between principal component analysis and other data reduction methods such as exploratory factor analysis is that the former analysis does not assume error variance and does not make any assumption about the existence of common factors while the latter analysis assumes error variance as well as the existence of few common factors driving data variation.
} 
components. The starting point of the analysis is the correlation among the variables. Indeed, the Pearson's correlations showed that there are positive and sufficient correlations among the variables capturing attitude to ER and EIP in decision-making (lowest $r=0.116 ; \mathrm{p}<0.000$ and highest $\mathrm{r}=0.377 ; \mathrm{p}<0.001$ ), and therefore the variables could be factored. Also, we tested the suitability of the respondent data for principal component analysis using the Kaiser-Meyer-Olkin ${ }^{2}$ test for sampling adequacy, which generated a value of 0.651 , indicating that such analysis is appropriate.

Performing principal component analysis, we found two factors underlying the five indicators. The variables value of ER and interest in ER belong to one factor with an eigenvalue of 1.034 and the variables problem solving, ER body as a common practice, and ER body involvement belong to another factor with eigenvalue 1.844 , both above the Kaiser criterion of 1 . Given that questions loaded to two factors and conceptually refer to related but not identical aspects of employee representation, we created two indices. The one captures attitude towards employee representation, defined as perceived attitude to ER, and is measured as the average of questions value of ER and interest in ER. The other factor captures perceived EIP in decision-making and is measured as the average of the three questions, i.e., problem solving, ER body as a common practice, and ER body involvement. Throughout the analysis the two indexes are standardized to have a 0 mean and a standard deviation equal to 1 .

To capture individual and other contextual factors that might be related to the main variables, the analysis incorporated additional predictors as well as control variables. Specifically, we used three dichotomous questions capturing the perceived degree of EIP in decision-making with respect to the organisation of work processes, recruitment and

\footnotetext{
${ }^{2}$ The test shows values between 0 and 1 with values smaller than 0.5 indicating that overall the variables have little in common to proceed with factor analysis, while values above that threshold are satisfactory for factor analysis.
} 
dismissals, occupational health and safety, training and career development, and working time arrangements in the establishment. Specifically, the questions ask whether the ER-body was informed about these decisions by management defined as low degree involvement (yes $=1$; no $=0$ ), whether employees were asked to give their views ahead of the decisions defined as medium degree involvement (yes $=1$; no $=0$ ), and whether they were involved in joint decision-making with management defined as high degree involvement $(y e s=1$; no $=$ 0). All variables refer to perceptions, however, we omit the term 'perceived' from the variable names for the remaining of this paper in order to simplify their names.

We also incorporated various controls for employee and firm level characteristics. We included a dichotomous question to capture whether an employee has received training related to her/his role as employee representative, defined as role training. We further controlled for gender $($ male $=1$; female $=0)$. We also used fixed effects for firm size $($ small $=$ 10-49; medium $=50-249 ;$ and large $=250$ and more), industries (a) mining and quarrying, manufacturing, electricity, gas, and water supply, b) construction, c) commerce and hospitality, d) transport and communication; e) financial services and real estate, and f) other services) following the Nomenclature Generale des Activites Economiques dans I Union Europeenne (NACE Rev. 1), and 12 countries.

\section{Findings}

Country-level analysis

First, we examined how CEE countries are clustered according to employee attitude to ER and EIP in decision-making. Table 2 presents the distribution of sample by country as well as the mean scores of the two variables, which vary considerably across countries. For example, positive attitude to ER is highest in Romania and lowest in Czech Republic, while EIP in decision-making is highest in Hungary and lowest in FYROM. The means help identify 
cluster of countries that behave similarly with respect to these different aspects of ER. We first show graphically the means by country and, for example, as Graph 1 depicts, Bulgaria, Croatia, FYROM, Poland, and Slovenia are characterized by lower positive attitude to ER and EIP in decision-making compared to Estonia, Hungary, Romania, Slovakia, and Lithuania while Czech Republic does not clearly belong to a cluster. To identify more refined clusters, we performed cluster analysis, which revealed two main clusters. As reported in Table 2, the first cluster includes Bulgaria, Croatia, Latvia, Poland, Slovenia, and FYROM and is characterised by lower means of positive attitude to ER and EIP in decision-making compared to the second cluster, which includes Czech Republic, Estonia, Lithuania, Hungary, Romania, and Slovakia.

[Insert Tables 2 and Graph 1 about here]

Individual-level analysis: Results

Although differences in levels between individual countries as well as cluster of countries with respect to positive attitude to ER and EIP in decision-making are apparent, higher levels of either variable do not necessarily reflect higher levels in ER body effectiveness. Therefore, a question that arises is whether an association between attitude to ER and EIP in decisionmaking on the one hand, and ER body effectiveness on the other, exists. In order to provide an answer to this question, we examine whether there is a positive or a negative association between a) attitude to ER and ER body effectiveness and b) EIP in decision-making and ER body effectiveness, using regression analysis.

The dependent variable, ER body effectiveness, is ordinal and thus we estimate ordered logit models, at the individual (employee representatives) level of analysis, as a function of attitude to ER and EIP in decision-making, and a number of control variables, i.e. role training, gender and firm size, industry, and country fixed effects. We checked the 
variance inflation factor (vif) in order to detect any multicollinearity problems among the variables. As a rule of thumb, obtaining vif values greater than 10 , merits further investigation. The highest vif value in our model is 5.85 suggesting no multicollinearity problems among variables. We continued with the estimation of order logits models and findings are presented in Table 3.

\section{[Insert Table 3 about here]}

Model 1 shows that (positive) positive attitude to ER has a positive, however marginally significant relationship with ER body effectiveness, while EIP in decision-making has a positive and highly significant relationship with ER body effectiveness. In Model 2, after controlling for the role training, gender, as well as firm size, industry and country fixed effects, we find similar relationships. With respect to the control variables, role training and gender have a positive and significant coefficient, showing that ER body effectiveness is greater for male employees, employees that have received training related to their role as employee representatives, and employees in larger firms than female employees, employees who have not received such training, and employees in smaller firms. All other variables are not significantly different from zero.

In the next step, we explored whether the country context has any important relevance. In Models 3 and 4, we test whether the strength of the relationship between positive attitude to ER and EIP in decision-making on one hand and ER body effectiveness on the other depends on context. We replicated Model 2 using two subsamples; one for each cluster identified at the country-level analysis. Results in models 3 and 4 showed that, holding all else constant, positive attitude to ER has an insignificant relationship with ER body effectiveness while EIP in decision-making has a positive and highly significant relationship in both models, nevertheless stronger in cluster one compared to cluster two. To compare the coefficients of EIP in decision-making between models 3 and 4, we carry out 
Wald tests using the seemingly unrelated estimation procedure (available as "suest" in Stata 12) and we find that the coefficients are statistically different (chi2 $=4.93$; p-value $=0.027$ ). This finding shows that although at the country level of analysis EIP in decision-making is more common in cluster two (Czech Republic, Estonia, Lithuania, Hungary, Romania, and Slovakia) than cluster one (Bulgaria, Croatia, Latvia, Poland, Slovenia, and FYROM), at the individual (employee representatives) level of analysis, the relationship between EIP in decision-making and ER body effectiveness is actually stronger in cluster one.

The paradox in the finding led us to examine further the relationship between EIP in decision-making and ER body effectiveness. In the final part of the analysis, we excluded the variable EIP in decision-making and introduced three variables capturing the degree of EIP (low, medium or high). Model 5 presents results for the full sample, which shows that holding all else constant, positive attitude to ER turns out to have a positive and significant relationship with ER body effectiveness. The model further shows that low degree involvement has no relationship with ER body effectiveness while ER body effectiveness is more likely when employees have medium or high degree involvement. In Models, 6 and 7, the full sample is split into cluster one and cluster two. In cluster one, positive attitude to ER has a positive and significant relationship with ER body effectiveness while in cluster two the relationship is not statistically significant. In addition, results show that any degree of involvement is positively related to ER body effectiveness in cluster one, nevertheless only medium and high degree involvement is related to ER body effectiveness in cluster two. Overall, these findings suggest that the degree of involvement matters as the results show that a high degree involvement has a stronger association with ER body effectiveness than a medium or a low degree involvement; even in some cases too little EIP is not effective.

\section{Discussion}


Using the 2013 European Company Survey, we explored the relationship of employee attitude to ER, EIP in decision-making and ER body effectiveness. We used an employee representative perspective to assess this and we focused on twelve post-communist CEE countries and explored three research questions.

Our first research question aimed at exploring how CEE countries are classified according to employee attitude towards ER and EIP in decision-making. Results showed that, at the county-level of analysis, there are mainly two clusters of countries that behave similarly. Specifically, we found that cluster one (Bulgaria, Croatia, Latvia, Poland, Slovenia, and FYROM) scores the lowest in positive employee attitude to ER and EIP in decisionmaking, while cluster two (Czech Republic, Estonia, Lithuania, Hungary, Romania, and Slovakia) scores the highest in these areas. Positive employee attitude towards representation, such as valuing the work of employee representation, expressing an interest in the outcomes of consultations and negotiations, and active participation in opportunities for decisionmaking, do matter in both contexts; more so for cluster two, which shows more positive employee attitude to ER and EIP in decision-making than cluster one. This is a valuable insight following research on the observed decline in union density and influence (Richbell et al., 2010; Sippola, 2009; Svetlik et al., 2010), in the variations in the ER systems used (Meardi et al., 2009) and in the institutional/legal context affecting the "culture" of EIP in companies (ETUI, 2018). It demonstrates a certain 'convergence' in each of these two Clusters in employee attitude to ER and EIP in decision-making regardless of the great variation in the region in terms of institutional histories (Ivlevs and Veliziotis, 2017; Soulsby, 2017) and transition paths to democracy (Hardy, 2014).

Our second research question aimed at exploring whether employee attitude towards ER and EIP in decision-making associate with ER body effectiveness in the CEE context and if there are any differences between country clusters. Focusing at the individual level of 
analysis, we found some evidence of an association between positive employee attitude to ER and ER body effectiveness and more solid evidence on the relationship between EIP in decision-making and ER body effectiveness. A plausible explanation for these findings is that when it comes to employee representation what matters more in evaluating the ER body as "effective" in influencing the management decisions is not whether there is positive employee attitude towards employee representation, but rather the degree of employee involvement in decision-making.

Furthermore, we explored whether there are any differences in these relationships between country clusters. Prior work has found that management commitment and support towards representative EIP in decision-making and the ER body, and employees' value of the process and outcomes of EIP is linked to ER body effectiveness by further establishing trust and commitment towards management and enhancing levels of work engagement (Franca and Pahor, 2014). As such, and because at the country level of analysis positive attitude to ER and EIP in decision-making are more common in cluster two, we would expect to see that the particular cluster would more likely depict higher ER body effectiveness compared to cluster one. Contrary to our expectations, at the individual level of analysis we found some evidence showing that more positive employee attitude to ER is related to effectiveness in cluster one but not cluster two. We also found evidence showing that the relationship between EIP in decision-making and ER body effectiveness is stronger in cluster one and weaker in cluster two.

In an effort to understand this finding further, our third question aimed at exploring how the degree (low, medium, high) of EIP in decision-making is related to ER body effectiveness. The results revealed that overall the perceived degree of involvement matters as high involvement has a stronger association with ER body effectiveness than a medium or a low involvement. Also, the results show that in some cases too little EIP in decision- 
making, i.e., when ER-body is informed about decisions by management after the event rather than inputting ahead of the decisions or being involved in joint decision-making with management, would have no influence on management decisions. Also, in both clusters, it is preferable to have some EIP in decision-making but not "too little".

In a further attempt to understand these findings, we looked into the reasons that may account for these differences between the two clusters, particularly how the outcome of the transition into democracy and the process of accession to the EU for most of the CEE countries might have affected the "culture" of ER and EIP in decision-making in these contexts in terms of the subjective perception of employees of EIP practices inside organisations (Edwards and Edwards, 2015: 133) and the employee expectations about the nature of EIP (Kessler et al., 2004). We looked at current evidence on the ER practices at board-level in private enterprises in the CEE context (Table 1). This evidence can help us explain the "culture" of EIP practices in organisations, levels of EIP in decision-making and employee attitude towards ER. In Table 1, cluster 1 contains a mix of countries (Bulgaria, Latvia, Poland, FYROM) which have no legislation allowing for ER at board level, however companies may allow ER at that level in some circumstances. Although in these four countries there is no widespread culture for ER in decision-making at board level, the way they involve employees at other levels appears to be effective. It also seems that in the remaining two countries in cluster 1 (Croatia and Slovenia), ER at board level is occurring mostly in large organisations. Our findings of positive employee attitude to ER and the relationship to ER body effectiveness in this cluster suggest that this positive "culture" towards EIP in decision-making may also be the norm across organisational sizes in these two countries.

In Table 1, cluster 2 contains countries, such as Czech Republic and Hungary, with weakened ER at board level caused by new legislation. In Estonia, EIP in decision-making is 
at the management's discretion and there is no legal provision for ER at board level. Similarly, in Romania, although the norm is for union representatives to be invited to participate in management boards, they are excluded from the voting process. Lithuania shares similarities with countries belonging to cluster 1 in terms of no requirements for employee representation at board level, but the ER body is not effective in this country, contrary to Bulgaria, Latvia, Poland, FYROM (in cluster 1), which seems to have developed positive employee attitude to ER and ER body effectiveness, regardless of degree of involvement. While in Slovakia, legislation provides for a supervisory board to oversee the management board in private enterprises with 50 or more employees, this is not enough to lead to ER body effectiveness. This demonstrates that the institutional/legal context (Debono, 2017; Turner and D'Art, 2012) may play a part but the existence of institutional structures does not guarantee EIP in decision-making at work. In other words much depends on the actors in the process and we should not see them as "institution takers' but with the potential for significant agentic action" (Heery, 2015: 31).

\section{Conclusion}

The importance of our study lies in examining EIP in decision-making in the setting of the decline of collective representational forms across Europe and against the backcloth of the global financial crisis. We focused on the effectiveness of indirect forms of EIP in decisionmaking in post-communist CEE countries, which have undergone major transformations in their ER systems. These environments are generally seen as being characterised by weak EIP representational forms and negative perceptions of ER body effectiveness (Avdagic, 2005). Formal representation is limited and, where it exists, weak, because of the limited power and legitimacy of organised labour (Varga, 2013). 
All in all, this is a first study attempting to explore EIP in decision-making in a wide range of CEE countries. Future studies relying on further versions of the ECS survey should focus on confirming this study's findings and understanding further the relationship between employee attitude to ER, EIP in decision-making, and ER body effectiveness over time and, thus, establish better the causal ordering of effects. Moreover, our study explores these relationships from an employee representative perspective. Although the insights provided are valuable, at the same time they cannot provide us with a complete picture, as they exclude other stakeholders, namely management and the ER body perspectives. In addition, because all our variables were collected from a single source only, it raises concerns about possible issues associated with common method variance. Although prior work (e.g., Spector, 2006) has questioned the idea that data extracted from a single source cause automatically common method bias, combining information from other stakeholders can help us avoid such problems and provide a more holistic picture of EIP in decision-making in CEE countries.

At the same time EIP practices in CEE countries are still developing and more research is needed in order to clarify the process and direction of restructuring. For example, future research may obtain measures for the various constructs from different sources and explore attitude to ER, EIP in decision-making and ER body effectiveness in this context, taking also into consideration the management and ER body perspectives.

\section{References}

Allvin M and Sverke M (2000) Do new generations imply the end of solidarity? Swedish unionism in the era of individualization. Economic and Industrial Democracy 21(1): 71-95.

Avdagic S (2005) State-labour relations in East Central Europe: Explaining variations in union effectiveness. Socio-Economic Review 3(1): 25-53

Bengtsson M and Berglund T (2010) Negotiating alone or through the union? Swedish employees' attitudes in 1997 and 2006. Economic and Industrial Democracy 32(2): 223-242. 
Bohle A and Greskovits B (2007) Neoliberalism, embedded neoliberalism and neocorporatism: Towards transnational capitalism in Central-Eastern Europe. West European Politics 30(3): 443-466.

Brewster C (2004) European perspectives on human resource management. Human Resource Management Review 14(4): 365-382.

Bryson A and Freeman RB (2013) Employee perceptions of working conditions and the desire for worker representation in Britain and the US. Journal of Labour Research 34(1): 1-29.

Buttigieg DM, Deery SJ and Iverson RD (2014) Voice within trade unions? A test of the voice and loyalty hypothesis. Journal of Industrial Relations 56(1): 3-23.

Cooke FL, Wood G, Psychogios AG and Szamosi LT (2011) HRM in emergent market economies: evidence and implications from Europe. Human Resource Management Journal 21(4): 368-378.

Cotton JL, Vollrath DA, Froggatt KL, Lengnick-Hall ML and Jennings KR (1988). Employee participation: Diverse forms and different outcomes. Academy of Management Review 13(1): 8-22.

Cox A, Zagelmeyer S and Marchington M (2006) Embedding employee involvement and participation at work. Human Resource Management Journal 16(3): 250-267.

Debono M (2017). Attitudes towards trade unions in Malta. Economic and Industrial Democracy, first published 6 January 2017, DOI: 10.1177/0143831X16681482.

Dundon T, Wilkinson A, Marchington M and Ackers P (2004) The meanings and purpose of employee voice. The International Journal of Human Resource Management 15(6): 1149-1170.

Edwards T and Edwards MR (2015) Perceptions of employee voice and representation in the post-acquisition period: Comparative and longitudinal evidence from an international acquisition. Human Relations 68(1): 131-156.

European Trade Union Institute (2018) National industrial relations: Compare counties. Available at: www.worker-participation.eu/National-Industrial-Relations/CompareCountries (accessed 18 January 2019).

Field A (2000). Statistics using SPSS for Windows. London: Thousand Oaks.

Franca V and Pahor M (2014). Influence of management attitudes on the implementation of employee participation. Economic and Industrial Democracy 35(1): 115-142.

Freeman R, Boxhall P and Haynes P (eds) (2007) What workers say: Employee voice in the Anglo-American workplace. New York: Cornell University Press. 
Furåker B, Berglund T (2003) Are the unions still needed? Employees' views of their relations to unions and employers. Economic and Industrial Democracy 24(4): 573594.

Givan R and Hipp L (2012) Public perceptions of union efficacy: A twenty four country study. Labour Studies Journal 37(1): 7-32.

Hardy J (2014) Transformation and crisis in Central and Eastern Europe: A combined and uneven development perspective. Capital \& Class 38(1): 143-155.

Heery E (2015) Frames of reference and worker participation. In: Johnstone S and Ackers P (eds) Finding a voice at work: New perspectives on employment relations. Oxford: Oxford University Press, pp. 21-43.

Hirsl A, Muleskovic M and Spaseska M (2018) Survey on understanding and attitude towards employee participation in decision-making. Inclusion of employees into decisionmaking processes. Association of employers of Slovenia, Ljubljana, Slovenia. Available at: http://poslodavci.org/en/publications/inclusion-of-employers-intodecision-making-processes (accessed 18 January 2019).

Hyman R (2018) What future for industrial relations in Europe? Employee Relations 40(4): 569-579.

IDE International Research Group (1981) Industrial democracy in Europe: Differences and similarities across countries and hierarchies. Organization Studies 2(2), 113-129.

Ivlevs A and Veliziotis M (2016) What do unions do in times of economic crisis? Evidence from Central and Eastern Europe. European Journal of Industrial Relations 23(1): 8196.

Jeppesen HS, Jønsson T and Shevlin M (2011) Employee attitudes to the distribution of organisational influence: Who should have the most influence on which issues? Economic and Industrial Democracy 32(1): 69-86.

Johnstone S, Saridakis G and Wilkinson A (2019) The global financial crisis, work and employment. Economic and Industrial Democracy, in press.

Kankaraš M and Van Houten G (2015) Third European company survey 2013. Dublin: The European Foundation for the Improvement of Living and Working Conditions.

Kessler I, Undy R and Heron P (2004) Employee perspectives on communication and consultation: Findings from a cross-national survey. The International Journal of Human Resource Management 15(3): 512-532. 
Korkut U, de Ruyter A, Maganaris M and Bailey D (2016) What next for unions in Central and Eastern Europe? Invisibility, departure and the transformation of industrial relations. European Journal of Industrial Relations 23(1): 65-80.

Larsen TP and Navrbjerg SE (2013) The economic crisis: Testing employee relations. Economic and Industrial Democracy 36(2): 331-353.

Lee AS and Trappmann V (2014) Overcoming post-communist labour weakness: Attritional and enabling effects of multinationals in Central and Eastern Europe. European Journal of Industrial Relations 20(2): 113-129.

Leszczynski D (2015) Emerging varieties of capitalism in transition countries: Literature review. International Journal of Management and Economics 48(1): 101-124.

Marchington M (2015) The role of institutional and intermediary forces in shaping patterns of employee involvement and participation (EIP) in Anglo-American countries. The International Journal of Human Resource Management 26(20): 2594-2616.

Marchington M and Kynighou A (2012) The dynamics of employee involvement and participation in turbulent times. The International Journal of Human Resource Management 23(16): 3336-3354.

McCann L and Schwartz G (2006). Terms and conditions apply: Management restructuring and the global integration of post-socialist societies. International Journal of Human Resource Management, 17(8): 1339-1352.

Meardi G, Marginson P, Fichter M, Frybes M, Stanojević M and Tóth A (2009). Varieties of multinationals: Adapting employment practices in Central Easter Europe. Industrial Relations 48(3): 489-511.

Mrozowicki A (2014) Varieties of trade union organising in Central and Eastern Europe: A comparison of the retail and automotive sectors. European Journal of Industrial Relations 20(4): 297-315.

Pateman C (1970) Participation and democratic theory. Cambridge: Cambridge University Press.

Pollert A (2000) Ten years of post-communist Central Eastern Europe: Labours tenuous foothold in the regulation of the employment relationship. Economic and Industrial Democracy 21(2): 183-210.

Pollert A (1999) Trade unionism in transition in Central and Eastern Europe. European Journal of Industrial Relations 5(2): 209-234. 
Psychogios AG (2010) Restructuring the employment relationship in South Eastern Europe? Total quality-based changes on managers' careers and job security. Employee Relations 32(3): 310-327.

Psychogios A, Brewster C, Missopoulos F, Kohont A, Vatchkova E and Slavic A (2014) Industrial relations in South-Eastern Europe: Disaggregating the contexts. The International Journal of Human Resource Management 25(11): 1592-1612.

Psychogios A, Szamosi LT, Prouska R and Brewster C (2016) A three-fold framework for understanding HRM practices in South European SMEs. Employee Relations 38(3): $310-331$.

Psychogios AG, Szamosi LT and Wood G (2010) Introducing employment relations in South Eastern Europe. Employee Relations 32(3): 205-211.

Psychogios A, Szamosi L, Brewster C and Prouska R (2019) Varieties of crisis and working conditions: A comparative study of Greece and Serbia. European Journal of Industrial Relations, first published 21 March 2019, https://doi.org/10.1177\%2F0959680119837101.

Richbell S, Szerb L and Vitai Z (2010) HRM in the Hungarian SME sector. Employee Relations 32(3): 262-280.

Riordan CM, Vandenberg RJ and Richardson HA (2005) Employee involvement climate and organisational effectiveness. Human Resource Management 44(4): 471-488.

Shadur MA, Kienzle R and Rodwell JJ (1999) The relationship between organizational climate and employee perceptions of involvement: The importance of support. Group \& Organization Management 24(4): 479-503.

Shapiro G (2000). Employee involvement: Opening the diversity pandora's box? Personnel Review 29(3): 304-323.

Sippola M (2009) The two faces of Nordic management: Nordic firms and their employee relations in the Baltic States. The International Journal of Human Resource Management 20(9): 1929-1944.

Soulsby A, Hollinshead G and Steger T (2017) Crisis and change in industrial relations in Central and Eastern Europe. European Journal of Industrial Relations 23(1): 5-15.

Spector PE (2006). Method variance in organizational research truth or urban legend?

Organizational Research Methods, 9(2): 221-232.

Strauss, G (2006) Worker participation: Some under-considered issues. Industrial Relations: A Journal of Economy and Society 45(4): 778-803. 
Strauss G (1998) An overview. In: Heller F, Pusic E, Strauss G and Wilpert B. (eds) Organizational participation: Myth and reality. Oxford: Oxford University Press, pp. 8-39.

Svetlik I, Barisic AA, Kohont A, Miric AA, Slavic A, Vaupot Z and Poor J (2010) Human resource management in the countries of the Former Yugoslavia. Review of International Comparative Management 11(5): 807-833.

Turner T and D'Art D (2012) Public perceptions of trade unions in countries of the European Union: A causal analysis. Labour Studies Journal 37(1): 33-55.

Tyler TR (1987) Conditions leading to value expressive effects in judgments of procedural justice: A test of four models. Journal of Personality and Social Psychology 52(2): 333-344.

Van den Berg A, Van Witteloostuijn A, Boone C and Van der Brempt O (2018) The performance effects of attitudes of management vis-à-vis employee representatives in Belgium. Personnel Review 47(1): 133-149

Varga M (2013) Refocusing studies of post-communist trade unions. European Journal of Industrial Relations 19(2): 109-125.

Wilkinson A, Dundon T and Marchington M (2013) Employee involvement and voice. In: Bach S and Edwards M (eds) Managing human resources, Oxford: Blackwell, pp. 268-288.

Wilkinson A, Gollan P, Marchington M and Lewin D (2010) Conceptualizing employee participation in organisations. In: Wilkinson A, Gollan PJ, Marchington M and Lewin D (eds) The Oxford handbook of participation in organisations. Oxford: Oxford University Press, pp. 1-25.

Williams CC (2015). Evaluating cross-national variations in envelope wage payments in East-Central Europe. Economic and Industrial Democracy 36(2): 283-303.

\section{Funding acknowledgments}

This research received no specific grant from any funding agency in the public, commercial, or not-for-profit sectors.

\section{Declaration of conflicting interests}

The Authors declare that there is no conflict of interest. 
Table 1. Employee representation in Central and Eastern Europe

\begin{tabular}{|c|c|c|c|c|c|c|}
\hline Country & $\begin{array}{l}\text { System } \\
\text { body) (1) }\end{array}$ & $\begin{array}{l}\text { Body with information } \\
\text { and consultation rights } \\
\text { (2) }\end{array}$ & $\begin{array}{lr}\text { Trade } & \text { union } \\
\text { involvement } & \text { in } \\
\text { information } & \text { and } \\
\text { consultation (3) } & \end{array}$ & 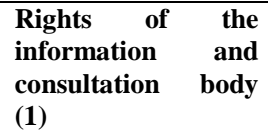 & $\begin{array}{l}\text { Main bodies in ECS } \\
2013(3)\end{array}$ & Board-level representation in private companies (4) \\
\hline Bulgaria & $\begin{array}{l}\text { Dual channel } \\
\text { (trade union) }\end{array}$ & $\begin{array}{l}\text { Elected representatives } \\
\text { or trade unions }\end{array}$ & $\begin{array}{lr}\text { Through (high) } & \text { union } \\
\text { membership } & \text { among } \\
\text { employee } & \\
\text { representatives } & \end{array}$ & $\begin{array}{l}\text { Information; } \\
\text { Consultation }\end{array}$ & $\begin{array}{l}\text { Employee } \\
\text { representatives } \quad(38 \%) ; \\
\text { Employee } \\
\text { representatives and } \\
\text { consultation }(34 \%)\end{array}$ & $\begin{array}{l}\text { No legal right for employees to participate at board level, } \\
\text { although employee representatives can have a consultative role } \\
\text { in shareholders' meeting under certain circumstances and only } \\
\text { for social issues. }\end{array}$ \\
\hline Croatia & $\begin{array}{l}\text { Dual channel } \\
\text { (works council) }\end{array}$ & Works councils & $\begin{array}{l}\text { Through (high) union } \\
\text { membership among } \\
\text { works councillors }\end{array}$ & $\begin{array}{l}\text { Information; } \\
\text { Consultation; } \\
\text { Codetermination } \\
\text { (specific issues) }\end{array}$ & $\begin{array}{l}\text { Trade union }(87 \%) ; \\
\text { Works council }(13 \%)\end{array}$ & $\begin{array}{l}\text { Employee representation at board level is present but limited to } \\
\text { a single member representing employees and most frequently } \\
\text { observed in larger limited companies. Limited companies can } \\
\text { choose between a two-tier and a one-tier structure but need to } \\
\text { have a two-tier structure when are larger in size and meet some } \\
\text { other conditions. Legislation states that employee } \\
\text { representatives have the same legal position as other board } \\
\text { members. }\end{array}$ \\
\hline $\begin{array}{l}\text { Czech } \\
\text { Republic }\end{array}$ & $\begin{array}{l}\text { Dual channel } \\
\text { (trade union) }\end{array}$ & $\begin{array}{l}\text { Trade unions or, where } \\
\text { no unions present, } \\
\text { employee councils }\end{array}$ & $\begin{array}{lr}\begin{array}{l}\text { Information } \\
\text { consultation } \\
\text { via union }\end{array} & \text { and } \\
\text { (mainly) }\end{array}$ & $\begin{array}{l}\text { Information; } \\
\text { Consultation; } \\
\text { Codetermination } \\
\text { (specific issues) }\end{array}$ & $\begin{array}{l}\text { Trade union }(93 \%) \\
\text { Works council }(7 \%)\end{array}$ & $\begin{array}{l}\text { Until January } 2014 \text { employees in privately owned companies } \\
\text { had the right to elect one third of the members of the } \\
\text { supervisory board, provided the company employed at least } 50 \\
\text { employees. In March } 2012 \text {, new legislation removed this right, } \\
\text { although companies can still voluntarily agree to employee } \\
\text { representation at board level. }\end{array}$ \\
\hline Estonia & $\begin{array}{l}\text { Dual channel } \\
\text { (Union or non- } \\
\text { union trustee) }\end{array}$ & Employee trustees & $\begin{array}{l}\text { Unions involved in } \\
\text { information and } \\
\text { consultation where they } \\
\text { exist }\end{array}$ & $\begin{array}{l}\text { Information; } \\
\text { Consultation }\end{array}$ & Employee trustee $(76 \%)$ & $\begin{array}{l}\text { There is no legal provision for employee representatives to } \\
\text { participate at board level. Occasionally trade union } \\
\text { representatives may participate at board meetings when } \\
\text { employee issues are discussed, but this is at management's } \\
\text { discretion. }\end{array}$ \\
\hline $\begin{array}{l}\text { FYROM } \\
\text { (4) }\end{array}$ & $\begin{array}{l}\text { Dual channel } \\
\text { (trade union) }\end{array}$ & $\begin{array}{l}\text { Elected trade union } \\
\text { representatives, } \\
\text { representatives for } \\
\text { safety and health at } \\
\text { work }\end{array}$ & $\begin{array}{lr}\begin{array}{l}\text { Information } \\
\text { consultation } \\
\text { via union }\end{array} & \text { and } \\
\text { (mainly) }\end{array}$ & $\begin{array}{l}\text { Information; } \\
\text { Consultation }\end{array}$ & $\mathrm{n} / \mathrm{a}$ & $\begin{array}{l}\text { Involvement of employees in decision-making is very limited } \\
\text { and the labour regulation does not contain any provisions for } \\
\text { employees to participate at board level. However, private } \\
\text { companies have the obligation to appoint a representative for } \\
\text { information and consultation issues. }\end{array}$ \\
\hline Hungary & $\begin{array}{l}\text { Dual channel } \\
\text { (works council) }\end{array}$ & Works councils & 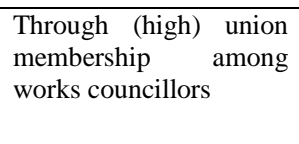 & $\begin{array}{l}\text { Information; } \\
\text { Consultation; } \\
\text { Codetermination } \\
\text { (specific issues) }\end{array}$ & $\begin{array}{l}\text { Works councils }(69 \%) \\
\text { Local trade union }(18 \%)\end{array}$ & $\begin{array}{l}\text { Employee representations make up one third of the members of } \\
\text { the supervisory board in companies with more than } 200 \\
\text { employees, but a } 2006 \text { legislation allows single-tier boards and } \\
\text { weakens employee rights. }\end{array}$ \\
\hline Latvia & $\begin{array}{l}\text { Dual channel } \\
\text { (trade union) }\end{array}$ & $\begin{array}{ll}\text { Trade } & \text { union } \\
\text { representatives } \\
\text { (predominant) }\end{array}$ & $\begin{array}{l}\text { Information and } \\
\text { consultation (mainly via } \\
\text { union) }\end{array}$ & $\begin{array}{l}\text { Information; } \\
\text { Consultation }\end{array}$ & $\begin{array}{l}\text { Authorized employee } \\
\text { representatives (46\%); } \\
\text { Trade union }(45 \%)\end{array}$ & $\begin{array}{l}\text { No statutory requirement for employees to be represented at } \\
\text { board level, although limited companies can choose whether to } \\
\text { have a supervisory board. }\end{array}$ \\
\hline
\end{tabular}




\begin{tabular}{|c|c|c|c|c|c|c|}
\hline Lithuania & $\begin{array}{l}\text { Dual channel } \\
\text { (trade union) }\end{array}$ & $\begin{array}{l}\text { Trade unions or works } \\
\text { councils }\end{array}$ & $\begin{array}{lr}\text { Information } & \text { and } \\
\text { consultation } & \text { (mainly) } \\
\text { via union } & \end{array}$ & $\begin{array}{l}\text { Information; } \\
\text { Consultation; } \\
\text { Codetermination } \\
\text { (specific issues) }\end{array}$ & $\begin{array}{l}\text { Health and safety } \\
\text { committee }(58 \%) ; \text { Trade } \\
\text { union }(21 \%)\end{array}$ & $\begin{array}{l}\text { No requirement for employee representation at board level, but } \\
\text { limited companies have a single-tier board. }\end{array}$ \\
\hline Poland & $\begin{array}{l}\text { Dual channel } \\
\text { (trade union) }\end{array}$ & Works councils & $\begin{array}{l}\text { Through (high) union } \\
\text { membership among } \\
\text { works councillors }\end{array}$ & $\begin{array}{l}\text { Information; } \\
\text { Consultation }\end{array}$ & 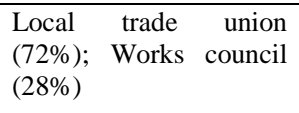 & $\begin{array}{l}\text { No statutory requirement for employees to be represented at } \\
\text { board level in private enterprises, although limited companies } \\
\text { can choose whether to have a supervisory board. }\end{array}$ \\
\hline Romania & $\begin{array}{l}\text { Dual channel } \\
\text { (trade union) }\end{array}$ & $\begin{array}{lr}\text { Trade } & \text { union } \\
\text { representatives } & \text { or, } \\
\text { where no union is } \\
\text { present, } \\
\text { employee elected } \\
\text { representatives }\end{array}$ & $\begin{array}{lr}\text { Information } & \text { and } \\
\text { consultation } & \text { (mainly) } \\
\text { via union } & \end{array}$ & $\begin{array}{l}\text { Information; } \\
\text { Consultation; } \\
\text { Codetermination } \\
\text { (specific issues) }\end{array}$ & $\begin{array}{l}\text { Employee } \\
\text { representatives (95\%) }\end{array}$ & $\begin{array}{l}\text { There is a single-tier board system. Union representatives } \\
\text { should be invited to participate in management boards to } \\
\text { discuss specific professional, economic, social and cultural } \\
\text { issues, but are excluded from the voting process. }\end{array}$ \\
\hline Slovakia & $\begin{array}{l}\text { Dual channel } \\
\text { (trade union) }\end{array}$ & $\begin{array}{l}\text { Trade union or works } \\
\text { council }\end{array}$ & $\begin{array}{lr}\text { Information } & \text { and } \\
\text { consultation } & \text { (mainly) } \\
\text { via union } & \end{array}$ & $\begin{array}{l}\text { Information; } \\
\text { Consultation; } \\
\text { Codetermination } \\
\text { (specific issues) }\end{array}$ & $\begin{array}{l}\text { Works council }(39 \%) \text {; } \\
\text { Trade union }(36 \%)\end{array}$ & $\begin{array}{l}\text { Employees have a right to a third of the seats on the } \\
\text { supervisory board in private companies employing more than } \\
50 \text { employees and meeting some other conditions, because the } \\
\text { Slovak system provides for a supervisory board to oversee the } \\
\text { management board which runs the company on a day-to-day } \\
\text { basis. }\end{array}$ \\
\hline Slovenia & $\begin{array}{l}\text { Dual channel } \\
\text { (works council) }\end{array}$ & Works council & \begin{tabular}{l}
\multicolumn{3}{l}{ Unions establish works } \\
councils, $\quad$ nominate \\
candidates
\end{tabular} & $\begin{array}{l}\text { Information; } \\
\text { Consultation; } \\
\text { Codetermination } \\
\text { (specific issues) }\end{array}$ & $\begin{array}{l}\text { Works council }(44 \%) \text {; } \\
\text { Trade union }(32 \%)\end{array}$ & $\begin{array}{l}\text { Employee representation at board level is present in larger } \\
\text { firms. Employee representatives have between a third and a } \\
\text { half of the seats on the supervisory board in companies with a } \\
\text { two-tier structure and at least a third of seats in companies with } \\
\text { a one-tier structure. Employees are entitled to board level } \\
\text { representation in companies meeting some requirements. }\end{array}$ \\
\hline
\end{tabular}

(1) Information derived from European Commission (2008), Employee representatives in an enlarged Europe, Publications Office of the European Union, Luxembourg (Table 4, pp. 47-49 and Table 7, pp.55-62), and European Commission (2006), Industrial relations in Europe 2006, Publications Office of the European Union, Luxembourg (Table 3.1, pp. 61-64) (updates made based on Eurofound 2011, Employee representation at establishment level in Europe, Dublin). (2) Information derived from Eurofound (2011), Information and consultation practice across Europe five years after the EU Directive, Dublin (Table 1, pp. 1-3 and Table 9, pp. establishment level in Europe, Dublin). (2) Information derived from Eurofound (2011), Information and consultation practice across Europe five years after the EU Directive, Dublin (Table 1, pp. 1-3 and Table 9, pp.
24-26). (3) Based on Eurofound (2015), Third European Company Survey - Direct and indirect employee participation, Publications Office of the European Union, Luxembourg, available at: https://www.eurofound.europa.eu/sites/default/files/ef_publication/field_ef_document/ef1545en_0.pdf (4) Eurofound (2015). Former Yugoslav Republic of Macedonia: Industrial relations profile, available at: https://www.eurofound.europa.eu/sites/default/files/ef_publication/field_ef_document/ef1545en_0.pdf (4) Eurofound (2015). Former Yugoslav Republic of Macedonia: Industrial relations profile, available at: Hirsl et al. (2018). 
Table 2. Distribution of sample by country

\begin{tabular}{lccccc}
\hline Country & $\begin{array}{c}\text { Number of } \\
\text { observations }\end{array}$ & $\boldsymbol{\%}$ & $\begin{array}{c}\text { Mean score } \\
\text { Employee attitude } \\
\text { to ER }\end{array}$ & $\begin{array}{c}\text { Mean score EIP in } \\
\text { decision-making }\end{array}$ & Clusters \\
\hline Bulgaria & 94 & 4.28 & -0.042 & -0.108 & 1 \\
Czech Republic & 173 & 7.88 & -0.278 & 0.317 & 2 \\
Estonia & 124 & 5.65 & 0.295 & 0.587 & 2 \\
Croatia & 146 & 6.65 & -0.197 & -0.139 & 1 \\
Latvia & 57 & 2.6 & 0.106 & -0.070 & 1 \\
Lithuania & 143 & 6.51 & -0.059 & 0.214 & 2 \\
Hungary & 249 & 11.34 & 0.169 & 0.604 & 2 \\
Poland & 514 & 23.42 & -0.033 & -0.333 & 1 \\
Romania & 220 & 10.02 & 0.362 & 0.218 & 2 \\
Slovenia & 215 & 9.79 & -0.264 & -0.224 & 1 \\
Slovakia & 154 & 7.02 & 0.066 & 0.361 & 2 \\
FYROM & 106 & 4.83 & -0.122 & -0.398 & 1 \\
\hline Total & 2,195 & 100 & & & \\
\hline
\end{tabular}


Table 3. Results of ordered logit for ER body effectiveness

\begin{tabular}{|c|c|c|c|c|c|c|c|}
\hline Variables & Model 1 & Model 2 & Model 3 & Model 4 & Model 5 & Model 6 & Model 7 \\
\hline & $\begin{array}{c}\text { Full } \\
\text { sample }\end{array}$ & $\begin{array}{c}\text { Full } \\
\text { sample }\end{array}$ & $\begin{array}{c}\text { Cluster } \\
1\end{array}$ & $\begin{array}{l}\text { Cluster } \\
2\end{array}$ & $\begin{array}{c}\text { Full } \\
\text { sample }\end{array}$ & $\begin{array}{c}\text { Cluster } \\
1\end{array}$ & $\begin{array}{l}\text { Cluster } \\
2\end{array}$ \\
\hline Employee attitude to ER & $\begin{array}{l}0.126^{*} \\
(0.068)\end{array}$ & $\begin{array}{l}0.125^{*} \\
(0.071)\end{array}$ & $\begin{array}{c}0.121 \\
(0.103)\end{array}$ & $\begin{array}{c}0.149 \\
(0.094)\end{array}$ & $\begin{array}{c}0.184 * * * \\
(0.063)\end{array}$ & $\begin{array}{l}0.248 * * * \\
(0.093)\end{array}$ & $\begin{array}{c}0.129 \\
(0.083)\end{array}$ \\
\hline EIP in decision making & $\begin{array}{c}0.347 * * * \\
(0.066)\end{array}$ & $\begin{array}{c}0.515 * * * \\
(0.073)\end{array}$ & $\begin{array}{c}0.673 * * * \\
(0.109)\end{array}$ & $\begin{array}{c}0.326 * * * \\
(0.095)\end{array}$ & & & \\
\hline Low degree involvement & & & & & $\begin{array}{c}0.080 \\
(0.070)\end{array}$ & $\begin{array}{c}0.238 * * \\
(0.096)\end{array}$ & $\begin{array}{l}-0.058 \\
(0.100)\end{array}$ \\
\hline Medium degree involvement & & & & & $\begin{array}{c}0.471 * * * \\
(0.077)\end{array}$ & $\begin{array}{c}0.368 * * * \\
(0.104)\end{array}$ & $\begin{array}{c}0.575^{* * *} \\
(0.113)\end{array}$ \\
\hline High degree involvement & & & & & $\begin{array}{c}0.782 * * * \\
(0.076)\end{array}$ & $\begin{array}{c}0.841 * * * \\
(0.106)\end{array}$ & $\begin{array}{c}0.770^{* * * *} \\
(0.107)\end{array}$ \\
\hline Role training & & $\begin{array}{c}0.391 * * * \\
(0.138)\end{array}$ & $\begin{array}{c}0.474 * * * \\
(0.179)\end{array}$ & $\begin{array}{c}0.117 \\
(0.205)\end{array}$ & $\begin{array}{c}0.371 * * * \\
(0.123)\end{array}$ & $\begin{array}{c}0.449 * * * \\
(0.159)\end{array}$ & $\begin{array}{c}0.186 \\
(0.183)\end{array}$ \\
\hline Gender & & $\begin{array}{l}0.512 * * * \\
(0.143)\end{array}$ & $\begin{array}{c}0.455^{* *} \\
(0.186)\end{array}$ & $\begin{array}{c}0.304 \\
(0.216)\end{array}$ & $\begin{array}{c}0.437 * * * \\
(0.128)\end{array}$ & $\begin{array}{c}0.494 * * * \\
(0.169)\end{array}$ & $\begin{array}{c}0.097 \\
(0.187)\end{array}$ \\
\hline Firm size: medium & & $\begin{array}{l}0.065 \\
(0.187)\end{array}$ & $\begin{array}{c}0.353 \\
(0.254)\end{array}$ & $\begin{array}{l}-0.256 \\
(0.272)\end{array}$ & $\begin{array}{c}0.012 \\
(0.172)\end{array}$ & $\begin{array}{c}0.211 \\
(0.237)\end{array}$ & $\begin{array}{l}-0.289 \\
(0.248)\end{array}$ \\
\hline Firm size: large & & $\begin{array}{c}0.312 \\
(0.196)\end{array}$ & $\begin{array}{l}0.543 * * \\
(0.262)\end{array}$ & $\begin{array}{l}-0.078 \\
(0.276)\end{array}$ & $\begin{array}{c}0.239 \\
(0.178)\end{array}$ & $\begin{array}{c}0.344 \\
(0.243)\end{array}$ & $\begin{array}{l}-0.108 \\
(0.245)\end{array}$ \\
\hline $\begin{array}{l}\text { Mining, manufacturing, } \\
\text { electricity, gas, water supply }\end{array}$ & & $\begin{array}{l}-0.071 \\
(0.191)\end{array}$ & $\begin{array}{l}-0.223 \\
(0.247)\end{array}$ & $\begin{array}{c}0.447 \\
(0.293)\end{array}$ & $\begin{array}{c}-0.048 \\
(0.171)\end{array}$ & $\begin{array}{l}-0.230 \\
(0.220)\end{array}$ & $\begin{array}{c}0.401 \\
(0.263)\end{array}$ \\
\hline Construction & & $\begin{array}{c}0.010 \\
(0.302)\end{array}$ & $\begin{array}{c}0.049 \\
(0.400)\end{array}$ & $\begin{array}{c}0.355 \\
(0.446)\end{array}$ & $\begin{array}{c}-0.083 \\
(0.271)\end{array}$ & $\begin{array}{l}-0.297 \\
(0.358)\end{array}$ & $\begin{array}{c}0.629 \\
(0.404)\end{array}$ \\
\hline Commerce and hospitality & & $\begin{array}{c}0.052 \\
(0.254)\end{array}$ & $\begin{array}{l}-0.334 \\
(0.341)\end{array}$ & $\begin{array}{c}0.574 \\
(0.378)\end{array}$ & $\begin{array}{c}0.153 \\
(0.230)\end{array}$ & $\begin{array}{l}-0.387 \\
(0.310)\end{array}$ & $\begin{array}{c}0.674 * * \\
(0.339)\end{array}$ \\
\hline Transport and communication & & $\begin{array}{c}0.001 \\
(0.295)\end{array}$ & $\begin{array}{l}-0.046 \\
(0.373)\end{array}$ & $\begin{array}{c}0.503 \\
(0.468)\end{array}$ & $\begin{array}{c}-0.028 \\
(0.254)\end{array}$ & $\begin{array}{l}-0.347 \\
(0.322)\end{array}$ & $\begin{array}{l}0.704 * \\
(0.397)\end{array}$ \\
\hline Financial services and real estate & & $\begin{array}{l}-0.474 \\
(0.313)\end{array}$ & $\begin{array}{l}-0.508 \\
(0.374)\end{array}$ & $\begin{array}{c}-0.685 \\
(0.540)\end{array}$ & $\begin{array}{c}-0.168 \\
(0.292)\end{array}$ & $\begin{array}{l}-0.442 \\
(0.351)\end{array}$ & $\begin{array}{l}-0.028 \\
(0.517)\end{array}$ \\
\hline Country & No & Yes & No & No & Yes & No & No \\
\hline Pseudo R-squared & 0.020 & 0.077 & 0.063 & 0.037 & 0.186 & 0.173 & 0.157 \\
\hline Observations & 1,053 & 1045 & 603 & 442 & 1,327 & 760 & 567 \\
\hline
\end{tabular}

Notes: Levels of significance: *** $\mathrm{p}<0.01,{ }^{* *} \mathrm{p}<0.05,{ }^{*} \mathrm{p}<0.10$. Regression coefficients are reported, with robust standard errors in parentheses, clustered by country. "Yes" means that Models include country dummies and "No" means that Models do not include country dummies. 
Graph 1. Country representation of mean values of Employee attitude to ER against EIP in decision-making $(\mathrm{n}=12)$

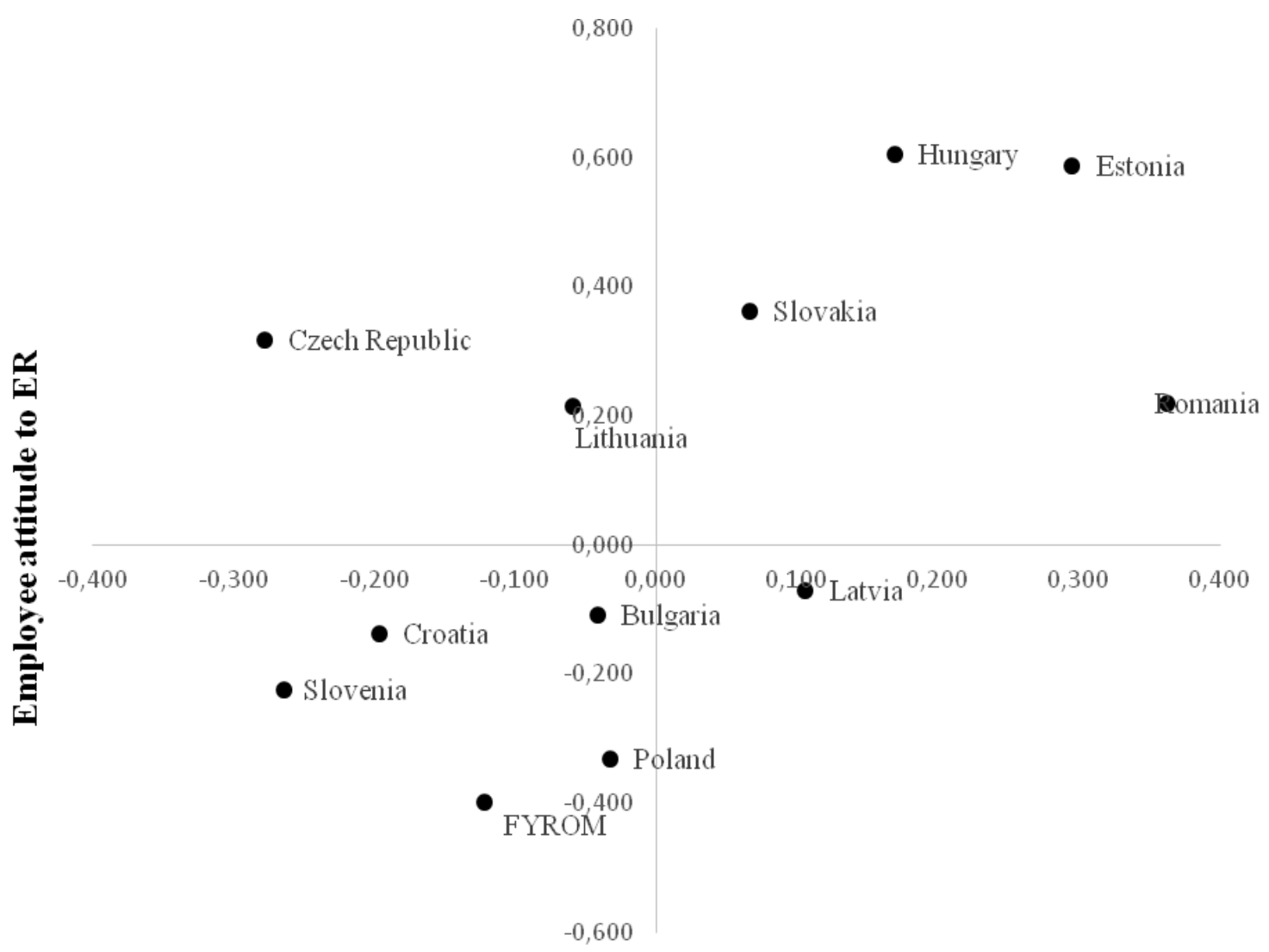

\section{EIP in decision making}

